\title{
An Exploratory Study on Management Support Services and Its effects on the Quality Service Delivery of Internal Auditors in the Northern Ghana
}

Dawuda $A^{*}$, Ataribanam S and Joseph AA

Department of Accountancy, Bolgatanga Polytechnic, Ghana

\begin{abstract}
The Internal Audit Department is a cornerstone for effective corporate governance. However, its effectiveness largely depends on the support of management. Therefore, this paper examines Management Support Services and its effects on the performance of Internal Audit Department in the Public Sector of Ghana. An exploratory research approach was deployed for this study. The respondents include Management, External Auditors and Heads of Internal Audit Departments in the three regions of the Northern Ghana. A total sample size of 170 was used. It was discovered that the Internal Auditors were not satisfied with the support services that management provide. There was strong positive correlation between Management Support Services and the Internal Audit performance. The key support services that influence Internal Audit performance were management commitment to working with Internal Auditors to develop Internal Auditor Charter and providing adequate logistics. On the basis of these findings, the paper recommends that Management should see internal audit unit as a strategic business unit in creating value and give it the necessary support. The Internal Audit Agency should be restructured with constitutional powers to recruit, train, determine condition of service and post internal auditors to all public institutions.
\end{abstract}

Keywords: Management support services; Internal audit charter; Adding value; Internal audit agency

\section{Introduction}

In recent times, internal audit has received much attention and it is required that, especially public sector institutions in Ghana to install internal audit departments [1]. This is to ensure effective corporate governance system and to increase citizen's confidence in the government regarding management of economic resources. Due to the complexity and competitive nature of business environment, more emphasis has been placed on internal audit function [2]. Enron, WorldCom, Arthur Anderson and Parmalat scandals called for the practice of sound and effective internal control system [3,4].

The Institute of Internal Auditors [5] defined internal audit as: "an independent, objective assurance and consulting activity designed to add value and improve an organization's operations. It helps an organization to accomplish its objectives by bringing a systematic disciplined approach to evaluate and improve the effectiveness of risk management, control and governance processes". This definition demonstrates how useful internal audit is to the stakeholders especially management. Dittenhofer [6] argued that if the quality of internal audit is maintained, it will contribute to the effectiveness and efficient operations of an organization. However, the quality of the internal audit unit depends on organizational independency, knowledge and experience, professional regulatory authority and the support services it receives from the management [7-10]. This study, therefore, focuses on Management Support Services. This is because management support service is pivotal to the effectiveness of internal audit department in service delivery [11]. According to Seif and Hussein [12] there is a positive relationship between management support and internal audit performance in the private sector. However, management employs internal auditors and at the same time serves an auditee. This puts internal auditors in a complex situation as their independency can be compromised. The internal audit unit would continue to be independent and effective as long as management allows it to be [13]. It is on the basis of this the researchers sought to undertake this study to assess the support the internal audit units receive from management and how this affects the quality delivery of internal audit services in the public sector.

\section{Literature Review}

Management support for internal audit unit is an important factor that determines the extent to which the unit can fulfil its objectives. The commitment and support of top management is essential for the effective internal audit. Management can demonstrate its support for internal audit by emphasizing the value of independent and objective internal auditing in identifying areas for improving performance quality and by implementing the recommendations of internal audit unit. In the case of district, municipal and metropolitan assemblies, the chief executives and other high government officials should show a high commitment in improving the quality of internal audit. Support for the internal audit unit in all parts of the organization to ensure, as far as possible that the auditors are treated with respect. It would be important that the role of internal audit and its powers are well understood within the organization.

To a large extent, internal audit is as useful as management allows it to be. The study of Abdulaziz and Nedal [14] revealed that the Internal Audit Department suffers due to less support from Senior Management. If internal audit issues reports which are critical of certain part of the organization and management takes no action for political reasons, this would only serve to undermine the internal audit function and reduces its effectiveness [15]. According to Mihret and Yismaw [16]

*Corresponding author: Dawuda A, Bolgatanga Polytechnic, Ghana; E-mail: abdawud2004@yahoo.com

Received October 13, 2017; Accepted October 25, 2017; Published November 02, 2017

Citation: Dawuda A, Ataribanam S, Joseph AA (2017) An Exploratory Study on Management Support Services and Its effects on the Quality Service Delivery of Internal Auditors in the Northern Ghana. Int J Account Res 5: 170. doi:10.4172/2472-114X.1000170

Copyright: (c) 2017 Dawuda A, et al. This is an open-access article distributed under the terms of the Creative Commons Attribution License, which permits unrestricted use, distribution, and reproduction in any medium, provided the original author and source are credited. 
management's failure to implement recommendations of internal audit has far reaching implications on the auditor's attitude towards improving audit quality, their commitment to develop a career as internal auditors. This is also in line with the thinking of Van Gansberghe [17], who submits that the implementation of audit recommendation is highly relevant to internal audit effectiveness. Mihret and Yismaw [16] also added that audit findings and recommendations would not serve much purpose unless management is committed to implement them. The findings of these studies implied that people would not find internal audit profession attractive to them and even those who take internal audit appointment may not demonstrate high professionalism in carrying out their duties if they do not see how they contribute to the overall achievement of organizational objectives.

Adams [18] used agency theory to explain that it is in the interest of management to maintain a strong internal audit department. The mandate, scope, methodology, and results should be determined solely by the internal audit charter without seeking consent from top management. When management defines the scope of the internal audit work, it does not allow the internal auditors to be independent. In areas where management is involved in misappropriation of resources may be excluded from the scope of audit work defined by the same management. It is the duty of management to define organizational setting of internal audit function, Sifile and Innocent [19] posited that, the performance of the internal audit unit can be improved if they get adequate support from management. Organizational setting includes the status of internal audit in the organizational structure; the probity of internal audit office, budgetary status of the internal audit office; the policies and procedures of the organization; and the existence of sound established criteria to evaluate auditee's practices and organizational independency. It provides the context in which the internal audit operates. Therefore, organizational setting can exert influence on the level of effectiveness that internal audit could achieve [7]. The organizational setting of every institution should allow the internal auditors to perform their duties without any hindrance. According to Zain et al. [20] an organizational settings with effective Audit Committee would enhance the work of Internal Audit Department.

In order to make internal audit effective, there should exist clear policies and procedures against which organizational practices are to be gauged. The policies and procedures should be well-understood by internal auditors so that they can help to improve upon those policies and procedures. According to Mihret and Yismaw [16], this component of the organizational setting factor rates fairly in terms of its influence on audit effectiveness. IIA explains that the chief executive must establish policies and procedures to guide the internal audit activity. These policies and procedures would specify the responsibilities of internal auditors and how audit reports should be presented and who should receive the reports. The audit activity must have sufficient funding relative to the size of its audit responsibilities. This important element should not be left under the control of the organization under audit because the budget impacts the audit activity's capacity to carry out its duties. The efficiency and effectiveness of internal audit unit depends on the availability of resources. Inadequate resources will limit the scope of audit work.

IIA [1] states that the chief audit executive must ensure that internal audit resources are appropriate, sufficient and effectively deployed to achieve the approved plan. The required resources needed by the internal audit unit are normally determined at the early stage of audit plan so that it can be incorporated into the master budget of the organization. The audit activities must have sufficient funding relative to the size of its audit responsibilities. This important element should not be left under the control organization under audit because the budget impacts the audit activity's capacity to carry out its duties [7]. The opportunity to seek for outside expertise when the need arises could also enhance the work of internal audit.

\section{Methodology}

\section{Research design}

The purpose of this study was to assess the support services management provides to internal auditors and how this affects their performance. Exploratory research approach was deployed for this study. The target population of the study comprises the Internal Auditors, officials of Ghana Audit Service and Management of some selected public sector institutions in the Northern Ghana. Purposive sampling technique was used to select 70 heads of internal audit department, 70 institutional heads and 30 officials from Ghana Audit Service making a sample size of 170 . The main instruments used for data collection were interviews and structured questionnaire with most questionnaire items being closed-ended using Likert Scale. The management of the respective institutions selected and the External Auditors were contacted to provide secondary data on the performance of the internal audit department. The performance was based on the extent of reliance on Internal Audit Department by external auditor and management appraisal of the department. The average scores were taken for the purpose of the analysis. The questionnaires were administered to the Internal Auditors. However, the researchers were not able to retrieve 8 questionnaires from the internal auditors making a response rate of $88.6 \%$. Statistical Product for Service Solution (SPSS) was used to process the data collected for analysis and discussion.

\section{Management support service model}

This model was developed by the researchers to test how management support services influence the quality delivery of internal audit services in the public sector.

The independent variables in this model include.

PAL: Providing Adequate Logistics; EIAR: Enforcing and Implementing Audit Recommendation; PRTIA: Providing Regular Training for Internal Auditors; PGCS: Providing Good Condition of Service; CDIAC: Commitment to working with internal auditors to Develop Internal Auditor Charter; AIAPrA: Allowing the internal audit unit to do Pre-Audit of all transactions; IIAPDM: Involvement of Internal Auditors in Planning and Decision Making; X: Other variables; The dependent variable is the Quality Internal Audit Service (QIAS).

Therefore, $\mathrm{QIAS}(\mathrm{Y})=\mathrm{X}_{0}+\mathrm{X}_{1} \mathrm{PAL}+\mathrm{X}_{2} \mathrm{EIAR}+\mathrm{X}_{3}$ PRTIA $+\mathrm{X}_{4} \mathrm{CDIAC}+$ $\mathrm{X}_{5} \mathrm{AIAPrA}+\mathrm{X}_{6} \mathrm{IIAPDM}+\mathrm{X}_{7} \mathrm{PGCS}$

In this model, there is a direct relationship between internal audit service delivery and the management support services. This suggests that if management improves upon its service provision to the internal audit unit, the internal audit service delivery will invariably improve. To test the data obtained from the field, the paper used linear regression analysis to establish how the independent variables predict the outcome of Quality Internal Audit Service (QIAS).

\section{Results and Discussion}

\section{Introduction}

This study examined the support services that management provides to the Internal Auditors and how this affects their performance. 
Descriptive statistics and linear logistic regression were used to present the data obtained from the respondents.

\section{Management support services}

As per the professional standards of Institute of Internal Auditors, management support is one of the key areas that will ensure effective delivery of internal audit service in the public sector. Therefore, the researchers sought to find out how the internal auditors were satisfied with the services their management provides. The evidence is depicted in Table 1 blow It was observed that, majority (41) representing 66\% of the Internal Auditors were not satisfied with the support services that management provides. While $14(23 \%)$ were satisfied with management support services, $7(11 \%)$ remained undecided. Those who were not satisfied with the services that management provides were of the view that management pays less attention to them in terms of supporting budgetary status of the departments and enforcing their audit recommendations. They also argued that management limits their scope of work and access to audit evidence was difficult for them in most cases. Their position was confirmed by the External Auditors as basis for not relying on the work of Internal Auditors. This evidence casts doubt on the ability of the Internal Auditors to carry out an independent and objective consultative and assurance services to their



Figure 1: Internal Auditors Perception of Management Support Services. institutions as management fail to create an enabling environment for them and to integrate the department properly into the corporate governance system (Figure 1).

To empirically establish whether management support services influence performance of Internal Auditors, linear logistic regression was performed. The evidence is depicted in Tables 1 and 2. Statistical evidence from Table 1 revealed the management support services have great influence on the performance of the internal auditors. For instance the commitment of management to working with internal auditors to develop Internal Auditor Charter (.751), providing Adequate Logistics (.682), Allowing the internal audit unit to do PreAudit of all transactions (.657), Enforcing and Implementing Audit Recommendation (.577) show strong positive correlation with the performance of the internal auditors. Providing Regular Training for Internal Auditors (.355) shows weak positive correlation while involvement of Internal Auditors in Planning and Decision Making (-.066) and Providing Good Condition of Service (-.107) show a very weak negative correlation. This suggests that if even their condition of service is good and other management support services are executed poorly, it would not yield any good performance. It is evidenced that for any effective internal audit to take place, management must support the development of internal audit charter as it serves as a legal document that binds all the parties to fulfill their part of the obligations. It is good for the internal auditors as they derive their powers and responsibilities from it. It can also be deduced that, resourcing the unit is the way to go if management wants to derive full benefits from it. To ensure effective risk management, the internal auditors should be allowed to do pre-audit of all transactions. This will make them to be proactive to anticipate risk and assist management with strategies to minimize the effects of the risk or even prevent them from happening.

The study went further to estimate individual management support services contribution to the performance of the internal auditors. The evidenced is presented in Table 2 below.

Dependent Variable: How would you rate the performance of the internal audit department? (Table 2a)

\begin{tabular}{|c|c|c|c|c|c|c|c|c|c|}
\hline \multicolumn{10}{|c|}{ Correlations } \\
\hline & & QIAS & PAL & EIAR & PRTIA & PGCS & CDIAC & AIAPrA & IIAPDM \\
\hline \multirow[t]{8}{*}{ Pearson Correlation } & QIAS & 1 & 0.682 & 0.577 & 0.355 & -0.107 & 0.751 & 0.657 & -0.066 \\
\hline & PAL & 0.682 & 1 & 0.387 & 0.213 & -0.01 & 0.433 & 0.497 & -0.011 \\
\hline & EIAR & 0.577 & 0.387 & 1 & 0.302 & 0.082 & 0.519 & 0.268 & 0.001 \\
\hline & PRTIA & 0.355 & 0.213 & 0.302 & 1 & -0.132 & 0.161 & 0.109 & -0.033 \\
\hline & PGCS & -0.107 & -0.01 & 0.082 & -0.132 & 1 & 0.052 & -0.078 & 0.045 \\
\hline & CDIAC & 0.751 & 0.433 & 0.519 & 0.161 & 0.052 & 1 & 0.415 & 0.026 \\
\hline & AIAPrA & 0.657 & 0.497 & 0.268 & 0.109 & -0.078 & 0.415 & 1 & -0.042 \\
\hline & IIAPDM & -0.066 & -0.011 & 0.001 & -0.033 & 0.045 & 0.026 & -0.042 & 1 \\
\hline
\end{tabular}

Table 1: Correlation Analysis of Support Services and Performance of Internal Auditors.

\begin{tabular}{|c|c|c|c|c|c|c|c|c|}
\hline \multicolumn{9}{|c|}{ Coefficients } \\
\hline & & B & Std. Error & Beta & & & Tolerance & VIF \\
\hline \multirow[t]{8}{*}{1} & (Constant) & .228 & .429 & & .531 & .597 & & \\
\hline & PAL & .309 & .074 & .282 & 4.148 & .000 & .647 & 1.546 \\
\hline & EIAR & .172 & .080 & .146 & 2.144 & .037 & .642 & 1.558 \\
\hline & PRTIA & .129 & .056 & .137 & 2.324 & .024 & .863 & 1.158 \\
\hline & PGCS & -.088 & .059 & -.085 & -1.508 & .138 & .939 & 1.065 \\
\hline & CDIAC & .406 & .069 & .410 & 5.861 & .000 & .612 & 1.635 \\
\hline & AIAPrA & .297 & .068 & .287 & 4.362 & .000 & .692 & 1.446 \\
\hline & IIAPDM & -.092 & .064 & -.084 & -1.449 & .153 & .883 & 1.132 \\
\hline
\end{tabular}

Table 2a: An Individual Contribution Estimate. 
Citation: Dawuda A, Ataribanam S, Joseph AA (2017) An Exploratory Study on Management Support Services and Its effects on the Quality Service Delivery of Internal Auditors in the Northern Ghana. Int J Account Res 5: 170. doi:10.4172/2472-114X.1000170

Page 4 of 4

\begin{tabular}{|c|c|c|c|c|c|c|c|c|c|}
\hline \multirow[t]{2}{*}{ Model } & \multirow[t]{2}{*}{$\mathbf{R}$} & \multirow[t]{2}{*}{ R Square } & \multirow[t]{2}{*}{ Adjusted R Square } & \multirow{2}{*}{$\begin{array}{l}\text { Std. Error of the } \\
\text { Estimate }\end{array}$} & \multicolumn{5}{|c|}{ Change Statistics } \\
\hline & & & & & R Square Change & F Change & df1 & df2 & Sig. F Change \\
\hline 1 & $.915^{\mathrm{a}}$ & .838 & .813 & .38746 & .838 & 34.215 & 8 & 53 & .000 \\
\hline
\end{tabular}

Model Summary: Statistical evidence suggests that the management support services identified in the model contribute significantly to the quality delivery of internal audit service in the public sector $\left(\mathrm{R}^{2}=.838\right.$; $\mathrm{F}=.000$ ) Table $2 \mathrm{~b}$. This means that about $83.8 \%$ of changes in internal audit performance are predicted by changes in management support services while $16.2 \%$ is presumed to be due to random variability. This evidence supports the assertion that the internal audit unit is effective as long as management allows it to be. The management support service that contributes most to the model is the commitment of management to working with internal auditors to develop Internal Auditor Charter (CDIAC) (.410) and this was followed by Allowing Internal Audit to do pre-audit of all transactions (AIAPrA) (.287) and providing adequate logistics (PAL)(.282). The researchers posit that for Internal Auditors to add value to an organization, Management must create an enabling environment for them. Any weakness of the Internal Audit Department can be attributed to the attitude of Management towards the Department.

\section{Conclusions and Recommendations}

Management support services are prerequisite for effective and quality internal audit. It can be deduced that the public sector institutions in Ghana are not making good use of internal audit departments as a cornerstone for effective corporate governance. This stems from the fact that, management failed to properly integrate the units into the governance structure as they receive less management support. The Installation of the internal audit departments in the various public sector institutions were merely to comply with regulations in the country rather than as value adding unit. The internal audit department needs full support of management to be able to effectively and efficiently discharge its functions.

On the basis of the above conclusions, the study recommends the following:

i. Management should work with the unit to develop the Internal Audit Charter that would allow some degree of organizational independence of the unit. The Internal Audit Charter serves as a legal document that binds all the parties to fulfill their part of the obligations. It is good for the internal auditors as they derive their powers and responsibilities from it.

ii. The budgetary status of the internal audit units should be improved so that audit activities can be completed on timely basis as audit recommendations lose value when not presented within the time frame.

iii. Management should see internal audit unit as a strategic business unit in creating value and give it the necessary support.

iv. Internal Audit Agency should be restructured with constitutional powers to recruit, train, determine condition of service and post internal auditors to all public institutions and to also have power to enforce implementation of internal audit recommendations.

\section{Further Study}

This paper recommends future research on comparative analysis of the performance of the Internal Auditors in both private and public sector institutions in Ghana.

\section{References}

1. The Institute of Internal Auditors (IIA) (2009) International Standards for the Professional Practice of internal auditing. Internal Audit Agency Act Ghana (2003) Act 658.

2. Diamond J (2002) The role of internal audit in Government financia management: An internal perspective. IMF working paper WP/02/94.

3. Harris R (2004) Presentation on Defining the role of internal audit: A Government perspective.

4. Parker LD (2005) "Corporate Governance Crisis down under Post-Enron accounting education and research inertia". European Accounting Review 14 303-314.

5. IIA (1999) Definition of Internal Auditing. Altemonte Springs FL: IA

6. Dittenhofer M (2001) Internal audit effectiveness: An expansion of present methods. Managerial Auditing Journal 16: 443-450.

7. Belay Z (2007) a study on effective implementation of internal audit function to promote Good Governance in the public sector. Managerial Auditing Journal.

8. Md Ali A, Gleock JD, Ali A, Ahmi A, Sahan MH (2007) Internal Audit in the State and Local Governments of Malaysia. Southern Africa Journal of Accountability and Auditing Research 7: 1-17.

9. Shamsuddin A (2014) Factors that determine th effectiveness of Internal Audit functions in the Malaysian Public Sectors. International Journal of Business, Economics and Law 5: 9-17 ISSN 2289-1552.

10. Abudu D, Gariba OA, Samuel EA (2015) The Organizational Independence of Internal Auditors in Ghana: Empirical Evidence from Local Government. Asian Journal of Economic Modelling 3: 33-45.

11. Samuel AA, Taiwo OA, James UM (2016) Promoting Good Corporate Governance through Internal Audit Function (IAF): The Nigeria Experience. International Business Research 9: 196-204.

12. Seif OA, Hussein AA (2012) Management Support and its impact on Performance of Internal Auditors at Jordanian Public Industrial Shareholding Companies. Global Journal of International Business Research 5: 52-64.

13. Goodwin J, Yeo TY (2001) Two factors affecting internal audit independence and objectivity: Evidence from Singapore. International Journal of Auditors 5 107-125.

14. Abdulaziz A, Nedal S (2013) the role of internal audit function in the public sector context in Saudi Arabia. African Journal of Business Management 7 443-454.

15. Gray I, Manson S (2000) The Audit Process: Principles Practice and Cases (2nded.) Bedford, London: Thomson Learning 9-12.

16. Mihret DG, Yismaw AW (2007) Internal audit effectiveness: An Ethiopian public sector case study. Managerial Auditing Journal 22: 470-484.

17. Van Gansberghe CN (2005) Internal auditing in the public sector: A consultative forum in Nairobi, Kenya. Shores up best practices for Government audit professionals in developing nations. Internal Auditor 62: 69-73.

18. Adams MB (1994) Agency theory and internal audit. Managerial Auditing Journal 9: 8-12.

19. Sifile O, Innocent NM (2014) Internal audit perceptions and their impact on performance of the internal audit function. IOSR Journal of Business and Management (IOSR-JBM) 16: 81-85.

20. Zain MM, Subramaniam NP, Goodwin J (2004) Audit Committee and Internal Audit Function Characteristics: Impact on internal audit contribution to financial statement. Managerial Auditing Journal 20-25 